\begin{tabular}{|c|} 
AFRICAN \\
EAST-ASIAN \\
AFFAIRS \\
\hline THE CHINA MONITOR \\
\hline
\end{tabular}

\title{
Crouching tigers, leaping lions? Developmental leadership lessons for South Africa from China and Malaysia
}

\author{
by Jo-Ansie van Wyk* \\ Department of Political Sciences \\ University of South Africa, South Africa
}

\begin{abstract}
Developmental leadership contributes to socio-economic development in developing states. China has, for example, set itself an ambitious power development, production and distribution agenda, whereas Malaysia's Big Fast Results Methodology is contributing to its economic development. Both these states offer some lessons for South Africa as Southern Africa's strongest economy. In fact, South African President Jacob Zuma's Operation Phakisa and its focus on, inter alia, the oceans or blue economy is directly taken from Malaysia's Big Fast Results Methodology. Moreover, South Africa has consolidated its relations, especially in the power sector with China, which is expanding its nuclear power sector at a very fast pace. Against the aforesaid, the article intends to analyse the relatively new concept, developmental leadership, in the context of declared developmental states; and using two case studies (electricity and oceans governance) for illustrative purposes to determine the applicability, impact and lessons from the Chinese and Malaysian models for South Africa as a developmental state.
\end{abstract}

*Author's note: An earlier version of this paper was presented at the Regional Conference on Building Democratic Developmental States for Economic Transformation in Southern Africa, organised by the United Nations Economic Commission for Africa (UNECA), Open Society Initiative for Southern Africa (OSISA), Southern African Trust and the United Nations Development Programme (UNDP). 20-22 July 2015, Pretoria, South Africa. 
AFRICAN

EAST-ASIAN

AFFAIRS

\section{Introduction}

The People's Republic of China (hereafter China), South Africa and Malaysia have embarked on different development trajectories due to, inter alia, each state's unique domestic and international needs and contexts. Despite these and other differences, similarities between these states also exist. All three states have, for example, significant development needs; are designated or self-confessed developmental states; have or continue to experience various types of undemocratic governments; are undergoing state transformation; and are emerging regional and international leading powers from the Global South, especially in the context of the United Nations (UN), the Non-Aligned Movement (NAM), the African Union (AU) and the Southern African Development Community (SADC).

China has become South Africa's largest trade partner (superseding the European Union) since President Zuma took office in 2009. In fact, Alden and Wu (2014: 15), concluded that 'two-way trade has flourished under the Zuma administration', with China also becoming one of Africa's largest trade, development and donor partners during this period. Besides China, Malaysia is perceived as an important leader and member of the NAM, giving Malaysia considerable status among its peers in the Movement as well as the Global South. Malaysia also has a developmental model often replicated by and proposed for developing states (Desta, 2012: 26-31). In Africa, South Africa and Tanzania, amongst others, adopted the Malaysian developmental model in 2014 and 2013 respectively (Zuma, 2014; Tanzania Invest, 2013).

The Chinese and Malaysian developmental trajectory reiterates the role and structure of the state in respect to development. In order to achieve socio-economic development, leaders of a state often transform and/or restructure the state to achieve and/or improve development. For the purpose of this contribution, these leaders are defined as developmental leaders, i.e. leaders with a specific developmental agenda (further clarification on the concept follows below). In China and Malaysia, leadersin this context, developmental leaders - have transformed and/or restructured the Chinese and Malaysian state to, inter alia, define and implement developmental 


\section{AFRICAN \\ EAST-ASIAN \\ AFFAIRS

policies wielding results. In China, for example, leaders embarked on an ambitious power development, production and distribution agenda, whereas Malaysia's Big Fast Results (BFR) methodology has been implemented and contributes to economic development. Given their experience, both China and Malaysia offer some lessons for South Africa which continues to face significant developmental challenges. Malaysia's success has been recognised by others. In fact, South African President Jacob Zuma's Operation Phakisa and its focus on, inter alia, the oceans or blue economy is directly taken from Malaysia's BFR methodology due to Malaysia's relative success in this sector. Apart from recognising Malaysia's success, South Africa's leaders also recognise China's relative successes. One consequence of this recognition is that South Africa has consolidated its relations with these states. This has been evident in the high levels of interaction between South Africa and these states, as well as increases in trade between these states.

Therefore, as state leaders are here considered to be the main development actors, the article intends to analyse the concept, developmental leadership, in the context of China, Malaysia and South Africa as declared developmental states; and using two specific case studies (electricity and oceans governance) to determine the applicability, impact and lessons from the Chinese and Malaysian development models for South Africa as a developmental state. A further motivation for this contribution is the fact that the literature on the developmental state (DS) and the democratic developmental state (DDS) is vast, and which, for brevity's sake is not repeated here but, where applicable, referred to. This is in contrast to scholarship on developmental leadership. Therefore, the contribution proceeds to clarify the concept developmental leadership before proceeding to an analysis of the selected case studies. In the third instance, the article focuses on Operation Phakisa as a state-led development initiative. The article then proceeds to deduce development lessons from China and Malaysia. The penultimate section attempts to offer some recommendations on developing developmental leadership. Final concluding remarks follow thereafter. 
AFRICAN

EAST-ASIAN

AFFAIRS

\section{Developmental leadership}

Concepts are the building blocks of theory and provide scientific explanations of events or phenomena. However, as Heywood (1999: 6) cautions, '(i)n politics ... the clarification of concepts is a particular [sic] difficult task'. Two types of concepts can be distinguished, namely normative and descriptive concepts. The former is described as values, referring to ideals, which should or must be achieved. Valueladen concepts include, for example, concepts such as freedom, tolerance and equality. These concepts often advance or prescribe specific forms of conduct, instead of describing events or phenomena. In contrast, descriptive or positive concepts refer to 'facts' which have an objective or demonstrable existence; referring to what is (Heywood, 1999: 7). Therefore, the utility of conceptual analysis as a method is that it provides greater clarity, which contributes to a shared understanding of the meaning and utility of a particular concept (Baldwin and Rose, 2009: 780781).

Therefore, the rationale for conducting a conceptual analysis of developmental leadership is prompted by several considerations. First, the concept has received scant scholarly attention. Second, literature on the concept is overshadowed by the literature on developmental states, predominantly focusing on the primacy of the state as the primary provider and enabler of development. This article, thirdly, focuses on the primacy of leaders rather than states and governments to mobilise and utilise state resources to achieve development. Finally, developmental leaders often establish developmental coalitions to achieve their objectives.

In defining developmental leadership and developmental coalitions, the article follows Leftwich (2009: 10-11):

Successful and sustained development depends crucially on whether and how various leaders and elites within and across the public and private domains are able to form sufficiently inclusive 'developmental coalitions' (or growth coalitions), formal or informal, which:

- Negotiate the fundamental political settlements which are essential 


\section{AFRICAN \\ EAST-ASIAN \\ AFFAIRS

for building the core institutions of effective states.

- Establish, maintain and implement the locally appropriate, legitimate and feasible institutional arrangements which facilitate economic growth and (inclusive) social development.

- Co-operate - locally, regionally, nationally, sub-nationally, sectorally or within and between organisations - to overcome major collective action problems and/or major political, economic and social problems.

Given the limited scholarship on developmental leadership, the contribution follows the pioneering work of Lyne de Ver's (2009: 9) whose definition of developmental leadership is:

the process of organising or mobilising people and resources in pursuit of particular ends or goals, in given institutional contexts of authority, legitimacy and power (often of a hybrid kind). Achieving these ends, and overcoming the collective action problems which commonly obstruct such achievements, normally requires the building of formal or informal coalitions of interests, elites and organisations, both vertical and horizontal.

Therefore, the meaning, implications and utility of developmental leadership are wide-ranging. In other words, leadership is contextual; purpose-driven; organisation and mobilisation of people and resources to achieve particular objectives; and involves co-operation in the form of coalitions and/or partnership (Lyne de Ver, 2009: 3-4). Whereas most scholarship on leadership focuses on leadership as/and management, developmental leadership focuses on the political process to achieve certain outcomes. Thus, developmental leadership entails leaders' harnessing of a state's political and 'infrastructural power' (Michael Mann in Huber et al., 2015: 14) to achieve development-related political and policy objectives. Developmental leadership also entails a leader's ability to initiate and maintain reform (formal or informal political coalitions including state and business actors co-operating and 
AFRICAN

EAST-ASIAN

AFFAIRS

working towards policy and institutional reform in order to achieve development but retaining their independence) (Peiffer, 2012: 7); and developmental coalitions (formal or informal political coalitions including state and business actors cooperating and working towards using these institutions to achieve development) (Leftwich, 2009:10-11) in a specific context.

Thus, the following elements of developmental leadership can be deduced: authority, legitimacy, influence and charisma. Moreover, a developmental leader should be cautious not to abuse state resources to compensate so-called developmental partners; and should, thus, prevent clientelism (exchanging goods or access for political support), prebendalism (use of public goods for personal gain by civil servants) and patronage (support in exchange for political support). In some instances, developmental leaders such as Singapore's Lee Kuan Yew and South Korea's Park Chung-hee have not been the shiniest examples of democratic developmental leadership; although both succeeded as developmental leaders in their developmental state contexts. Similarly, this is the case in China and Malaysia. Thus, this article distinguishes between democratic and undemocratic developmental leadership as two types of developmental leadership.

The next section focuses on developmental leaders in China's nuclear energy regime as an illustrative case study from which some lessons for South Africa can be learnt.

\section{China's nuclear energy regime}

Energy security is crucial in achieving and maintaining development and growth (Cherp and Jewell, 2011: 330-355). Like elsewhere, China's growth has been carbon energy intensive (WNA, 2015a); resulting in greater demands for energy and, pertinent to this contribution, China's efforts to energise the Chinese dragon to maintain and improve its exceptional annual growth (Zhao, 2013). Apart from increasing oil imports and developing gas resources, the Chinese government has also set ambitious targets for the expansion and development of its peaceful nuclear energy sector. Currently, China maintains 26 nuclear power reactors in operation, whereas 24 are under construction and a significant number is envisaged for the foreseeable future (until 2050) (WNA, 2015a); a consequence of policy development 


\section{AFRICAN \\ EAST-ASIAN \\ AFFAIRS

and implementation (outlined below) during the past decade.

In achieving its ambitious development and energy-related objectives, in February 2005, the National People's Congress (NPC) approved the so-called Renewable Energy Law, which includes incentives and regulations for the development of the country's renewable energy sector. Subsequent to this, the State Council established a State Energy Leadership Group under the leadership of Premier Wen Jiabao including Vice-Premiers Huang Ju and Zeng Peiyuan as deputy heads of the Group and the State Energy Leadership Office, as well as the energy focus of the Eleventh Five Year Plan; thus, signalling the high political priority of the country's energy security (Cheng, 2013: 6). Subsequent to these developments, various other energy reform initiatives followed to achieve the identified four main energy-related objectives, namely energy security; economic efficiency; social equity; and environmental protection (Meidan et al., 2013: 46-49). In October 2012, the State Council released a White Paper on Energy Policy, which increased the proportion of non-fossil energy sources such as nuclear energy. Following this, the National Development and Reform Commission (NDRC) adopted a national climate change plan in September 2014 and in November 2014, the State Council published the Energy Development Strategy Action Plan (2014-2020); calling, inter alia, for the launch of new nuclear power projects not only on coastal areas, but also inland (WNA, 2015a).

Against the aforesaid, several features of China's nuclear energy regime are evident. The country suffers from an energy deficit (WNA, 2015a); the nuclear energy regime is centrally driven and set out in the country's Five Year Plans (Meidan et al., 2013); nuclear power expansion is set to continue (WNA, 2015a); the Chinese government (and thus, not private actors) is the owner/operator of all of the country's nuclear organisations, utilities, and companies (WNA, 2015b); and China's 'heavy bureaucratic tradition' and consensual decision-making process results in lengthy policy processes (Meidan et al., 2013: 47).

More important to the contribution, is whether developmental leadership is present in China's nuclear energy regime. Evidence suggests that China's political 
AFRICAN

EAST-ASIAN

AFFAIRS

leadership is central to the country's nuclear energy regime (Cheng, 2013) but that this is not developmental leadership in terms of the working definition of developmental leadership in this contribution (Lyne de Ver, 2009: 9). In fact, the nature of the Chinese state and state leadership challenges the notion of developmental leadership, which in terms of Lyne de Ver's (2009: 9) definition presupposes a democratic state. However, this contribution argues that developmental leadership can operate in undemocratic environments and achieve developmental objectives. Whereas the Chinese leadership is engaged in the process of organising or mobilising people and resources in pursuit of particular goals in its institutional context of authority, and legitimacy, it has not built formal or informal coalitions of interests, elites and organisations existing in the private and public sector; especially due to the absence of a Chinese private sector in the country. At best, developmental leadership in China can be linked with what $\mathrm{Wu}$ (2015) terms, 'authoritarian capitalism', i.e. state-driven capitalism and central state monopoly of the developmental agenda.

In the Chinese context, another issue requires a reconsideration of developmental leadership in general and, in particular, in China, i.e. state transformation. State transformation occurs either by coercion, imposition and/or war, and/or by adopting policy models of other states (emulation, learning and knowledge sharing); whereas domestic determinants include, amongst others, levels of economic development, domestic coalitions, state-society relations and leaders. State transformation per se refers to 'fundamental shifts in the scope of state activities, bureaucratic capacities, purposes, instruments, and structures of authority' (Huber et al., 2015: 3-9, 13). It is generally accepted that China is a state in flux with unprecedented state transformation from a socialist state to a pseudo-socialist state with capitalist/neoliberalist features (Bolesta, 2015; Chow, 2015; Hameiri and Jones, 2015) or can be defined as a post-socialist developmental state (PSDS) (Bolesta, 2015: 227). When the notion of state transformation and developmental leadership is considered in the context of China, the 'fundamental shifts in the scope of state activities, bureaucratic capacities, purposes, instruments, and structures of authority' (Huber et al., 2015: 39,13 ) should be taken into account and, possibly, identify developmental leadership 


\section{AFRICAN \\ EAST-ASIAN \\ AFFAIRS \\ THE CHINA MONITOR}

sui generis in the context of China as a PSDS. Chow (2015), amongst others, refers to, for example, changes occurring in Chinese state-owned enterprises distancing themselves from the central government but responsible to the central government; the emergence and role of Chinese non-state actors in China; changes in the bureaucracy and provincial-central government relations. However, the Chinese leadership has initiated limited reform coalitions; limited due to, amongst others, the domination of the Chinese Communist Party (CCP), lack of privatisation and the preoccupation of maintaining a strong, stable state (Bolesta, 2015: 242).

Moreover, democratic developmental leadership in the context of democratic developmental coalitions is absent due to the lack of 'relational aspects' (Bolesta, 2015: 13) of the democratic developmental state (relations/coalition of state political elite; the state bureaucracy; the society; and business) despite its efforts to seek 'developmental legitimacy' (Bolesta, 2015: 242). It is also evident in the country's persisting developmental challenges such as societal inequality (Bolesta, 2015: 242) with leaders' reform initiatives predominantly benefitting the party elite and interests resulting in clientelism, prebendalism, patronage and 'rampant corruption' (Bolesta, 2015: 234) in China.

China's power, status and prestige, as well as its ideological and solidarity links with South Africa makes it's a very attractive model for South Africa to emulate. In fact, Sino-South African bilateral relations have moved beyond mere routine diplomacy to a strategic partnership. Yet, Pretoria's kowtowing and evident adaptation and conformity to Beijing is unique in its diplomatic relations (The Star, 23 March 2009). More on this follows later in the paper. The next section focuses on Malaysia as a selected case study.

\section{Malaysia's Big Fast Results}

Malaysia is also one of the $20^{\text {th }}$ century developmental states emerging from the socalled second wave of the developmental state; i.e. the emergence of East Asian developmental states (Jones Luong, 2015: 629). Adopting and adapting the development models of Asian Tigers such as Japan, South Korea and Taiwan, Malaysia embarked on a developmental state trajectory during the tenure of Prime 
AFRICAN

EAST-ASIAN

AFFAIRS

THE CHINA MONITOR

Minister Mahatir Mohammed (1981-2003) (Desta, 2012: 26-31). For the purpose of this section, a comprehensive analysis of the Malaysian developmental state is not presented. Instead, the focus is limited to Malaysia's more recent development initiative, the BFR methodology.

The Government of Malaysia adopted the strategy in $2009 / 10$ as a national development vision to address national key development priority areas such as poverty, crime and unemployment by 2025 (Idris Jala, 2014). For Malaysia (2014a), BFR 'means exactly what it sounds like: impactful and immediate consequences. But more than that, it's the standard operating protocol of the GTP [Government Transformation Programme] when it comes to assessing whether an initiative is good enough to be included in the stable of changes' (Malaysia, 2014a). Furthermore, the Government of Malaysia describes the BFR as 'about getting buy-in' while aiming to 'cultivate collaboration between ministries, government agencies and stakeholders, public and private, to define clear targets, clear direction and the clear allocation of resources' (Malaysia, 2014a). Moreover, the BFR is also about political and ideological expediency:

In short, BFR is about getting things done. It aims to rid the public of a ubiquitous concern - that the Government simply is unable to execute and deliver on programmes that otherwise sound great in theory. It's about ensuring that the initiatives put in place will do what they aim to do, and that they get done (Malaysia, 2014a).

The BFR strategy highlights some of the salient features of the Malaysian developmental state and developmental leadership. Returning to the contribution's working definition of developmental coalitions and leadership, Malaysia leaders and elites within and across the public and private domains were able to establish sufficiently inclusive 'developmental coalitions' (or growth coalitions), formal or informal, through the 8-step methodology of the strategy. The 8-step methodology, as described by the Minister in the Office of the Prime Minister of Malaysia, Senator Idris Jala (2014), entails:

1. Strategic Direction: determine the strategic direction required 


\section{AFRICAN \\ EAST-ASIAN \\ AFFAIRS

2. Labs: determine what needs to be done

3. Open Days: share the Lab findings with the population and incorporate their feedback

4. Roadmap: inform citizens of plan of action

5. Key Performance Indicators (KPIs) and Targets: determine KPIs to measure progress

6. Implementation of plan of action in communities, regional and national level

7. External validation of results achieved

8. Annual reporting and information sharing with population on achievements

Due to its developmental focus, community involvement, and external validation, the 8-step methodology has resulted in the implementation of locally appropriate, legitimate and feasible institutional arrangements which facilitate economic growth and (inclusive) social development in respect of the BFR strategy (Idris Jala, 2014).

The Malaysia GTP and its Vision 2020 are driving the BFR via the Performance Management and Delivery Unit (PEMANDU), established in September 2009 in the Prime Minister's Office. PEMANDU oversees the implementation, assessment and delivery of the GTP (aiming to improve access to public services; reducing crime; fighting corruption; assuring quality education; raising standards of living; improving rural development; improving urban transport; and addressing the cost of living) and the Economic Transformation Programme (ETP) (aiming to transform Malaysia into a high-income state by 2020) (PEMANDU, 2015). The GTP focuses on 'transformational change' by getting 'buy-in from all stakeholders from the rakyat [community] on the ground to the most senior Cabinet Ministers'; and, thus, a departure of 'Government knows best approach' of the past (Malaysia, 2014b); illustrative of a developmental coalition and leadership by organising or mobilising people and resources to achieve development.

Against the aforesaid, President Jacob Zuma undertook an official state visit to 
AFRICAN

EAST-ASIAN

AFFAIRS

Malaysia in August 2013. During this visit, the Government of Malaysia introduced him and his delegation to the BFR Methodology 'through which the Malaysian government achieved significant government and economic transformation within a very short time' (The Presidency, 2014). Upon Zuma's return and with the assistance of the Malaysian government, the BFR approach was adapted to the South African context and to 'highlight the urgency of delivery' the approach was renamed to Operation Phakisa ("phakisa" means "hurry up" in Sesotho) (The Presidency, 2014).

\section{Operation Phakisa and the blue economy}

Global consensus converges on the economic benefits and potential of the so-called blue economy, or maritime economy (UNCTAD, 2014). The United Nations Conference on Trade and Development (UNCTAD) estimated that, globally, almost 350 million jobs are linked to the oceans through fishing, aquaculture, coastal and marine tourism and research activities, with an additional one billion people relying on fish as their primary source of protein (UNCTAD 2014: 2). More than 200 million Africans where 39 of the 54 states and islands are littoral, rely on the ocean for food and nutrition, whereas the fisheries industry provides employment for more than 10 million Africans (AU, 2012: 8). In 2010, for example, South Africa's oceans economy contributed approximately ZAR 54 billion to the country's gross domestic product (GDP), with approximately 316, 000 people employed in the sector (South African Government News Agency, 19 July 2014). Supporting the said global consensus, South Africa's Minister of International Relations and Co-operation, Maite Nkoane-Mashabane, described the blue economy as the 'next frontier of global economic growth' (Nkoane-Mashabane, 2014).

A relatively recent concept, the blue economy, also referred to as the ocean or maritime economy, is defined as 'economic and trade activities that integrate the conservation and sustainable use and management of biodiversity, including maritime ecosystems, and genetic resources' (UNCTAD, 2014: 2). The concept has been adopted by various states, including several African and other developing regions.

Mauritius, for example, initiated its first Ocean Economy Roadmap in 2013 to take 


\section{AFRICAN \\ EAST-ASIAN \\ AFFAIRS

advantage of the economic potential of the island's oceans. Moreover, the Roadmap emphasises the need to unlock the economic potential of the country's exclusive economic zone (EEZ) 'by ensuring sustainable and co-ordinated utilisation of living and non-living resources' and by including tourism, seaports and seafood-related activities and sectors (UNCTAD, 2014: 6). In order to achieve these objectives, the government of Mauritius has established a national public-private task force, and plans to establish an ocean's business park and an ocean's research centre. It also plans to conduct a 'comprehensive regulatory review of the ocean's economy' (UNCTAD, 2014: 6). In January 2014, Seychelles, another African state, launched its own ambitions in 'The Blue Economy - Seychelles' vision for a Blue Horizon' (UN, 2014). According to the President of Seychelles, James Alix Michel (2015: 162-177), the country's blue economy strategy entails economic diversification; the creation of high value employment opportunities in the maritime industry; increasing the contribution of the country's maritime sector to Seychelles' GDP; and the sustainable development of the country's maritime environment.

Apart from implementing national blue economy policies, the notion of the blue economy was also addressed at conferences and adopted by multilateral organisations. In December 2013, the government of Portugal, for example, invited the AU to participate in its 'Blue Growth of the Atlantic' conference (AU, 2013). The AU, in the Final Communique of the $387^{\text {th }}$ Peace and Security Council on 29 July 2013, described the blue economy as the 'new frontline of Africa's renaissance' (AU, 2013). In January 2014, small island development states (SIDS) and coastal states attended the Blue Economy Summit in Abu Dhabi, United Arab Emirates (UN, 2014).

Operation Phakisa was officially launched on 19 July 2014. By President Zuma's own admission, Operation Phakisa is not an original idea as it is an 'adaptation' of the BFR Methodology of Malaysia, following President Zuma's visit in 2013 (Zuma, 2014). Operation Phakisa focusses exclusively on harnessing the socio-economic benefits of South Africa's vast maritime area. South Africa's maritime sovereignty includes a coastline of $3924 \mathrm{~km}$; an exclusive EEZ of $1,553,000 \mathrm{~km}^{2}$ and 4,340 $000 \mathrm{~km}^{2}$ maritime territory (Defence Review Committee, 2012: 7-2). These vast 
AFRICAN

EAST-ASIAN

AFFAIRS

maritime areas contribute to what can be called an additional tenth province of the Republic.

President Zuma explained the origins of Operation Phakisa as the result of a consultative process, including 'teams from government, labour, business, academia and other sectors to work together in experimental laboratories, to explore all possibilities and further unlock the potential of our country's vast coastline' (Zuma, 2014). These teams focus on four areas, or workstreams, namely:

- Marine Transport and Manufacturing

- Offshore oil and gas exploration

- Aquaculture

- Marine protection services and ocean governance (Zuma, 2014).

Speaking at the launch of Operation Phakisa, President Zuma outlined aspects of South Africa's blue economy whilst maintaining that South Africa's maritime economy have the 'potential to contribute up to ZAR 177 billion' to the country's GDP and create 'just over a million jobs by 2033' (Zuma, 2014). The rationale for Operation Phakisa is undoubtedly to enhance development. President Jacob Zuma's announcement of Operation Phakisa early in his second presidential term in 2014 was the latest in a series of government initiatives such as the National Development Plan (NDP) to stimulate development. However, the question remains: how appropriate and applicable are these transplanted models of development, and does it offer any developmental lessons?

\section{Development and developmental leadership lessons from China and Malaysia}

The development status of China and Malaysia oscillates between DS and PSDS. A self-confessed developmental state, South Africa is increasingly adopting a 'Look East' (i.e. favouring ties with states in Eurasia, the Middle and Far East rather than ties with traditional partners in the West) approach in its foreign policy and development strategy. For analytical purposes, South Africa's nuclear energy expansion plan and the development of its blue economy have been selected as 


\section{AFRICAN \\ EAST-ASIAN \\ AFFAIRS \\ THE CHINA MONITOR}

comparative case studies in order to draw lessons for the improvement of development through developmental coalitions and leadership.

Both China and South Africa's energy demands are increasing; and have been identified as a priority development issue with nuclear energy expansion chosen as a solution to meet future energy demands, achieve energy security, and achieve sustainable levels of development. Whereas China has nuclear weapons, South Africa has dismantled its nuclear weapons and terminated its nuclear weapons programme. The nuclear regime in both China and South Africa are tightly controlled by the state with no private sector involvement in nuclear power generation and distribution. In the case of China, there is a lack of evidence to suggest that the Chinese government is approaching its energy security as a human security issue. There is some evidence that the Chinese government has exercised developmental leadership by initiating and establishing sufficiently inclusive developmental coalitions to address the country's energy-related development needs through locally appropriate, legitimate and feasible institutional arrangements that facilitate economic growth and (inclusive) social development. Whereas Malaysia has established various public-private developmental coalitions, China, and in particular the nuclear energy sector, has established development coalitions within the state among state actors. This bureaucratic version of developmental coalitions and developmental leadership is unique but has, in terms of the working definition of the contribution, wielded some results as Chinese developmental leaders have indeed organised people, resources and institutions to achieve specific developmental objectives.

Like many other sectors in China, the governance of the nuclear power sector remains statist and elitist with little to none democratic oversight (Wu 2015). Here, the Chinese model is similar to the current South African situation where the stateowned power utility, Eskom, maintains a monopoly on the power sector in the country. However, in the South African case, several indications of developmental leadership and developmental coalitions in the country's power sector are evident. This includes, amongst others, the South African government's agreements with independent power producers (IPPs), the stimulation of the renewable energy 
AFRICAN

EAST-ASIAN

AFFAIRS

resources sector and energy-related tax incentives. However, these developmental leadership and coalitions are not evident in the country's embarking on a nuclear power expansion plan. Decisions relating to the latter are overseen by a committee under the leadership of President Zuma, and coalitions formed seem to entrench existing state-business elite relations benefiting the elite to the detriment of government's aim of achieving broad-based black economic empowerment (BBBEE). Moreover, developmental coalitions on nuclear energy are limited and exclusive. A notable example occurred in June 2015 when the China National Nuclear Corporation (CNNC) signed a strategic co-operation agreement with the Chinese Sichuan province; following an earlier co-operation agreement signed in 2010 (World Nuclear News, 8 June 2015). Thus, China's model of undemocratic energy governance cannot and should not be replicated in South Africa.

South Africa's acknowledgement of its application of Malaysia's BFR raised considerable concerns signalling the importance of knowledge sharing (Balozi, Othman and Issa, 2014: 7-21). First, despite Malaysia's success as a developmental state, the country has not been able to meet all its developmental needs. Whereas the BFR focuses on improving public and social services, and improving the income status of ordinary Malaysians, it remains to be seen whether its 8-step methodology is applicable to South Africa, in general, and to the blue economy specifically; also since the project was announced less than a year ago. Second, at the time of writing, Operation Phakisa has moved to its second focus area, namely health, with little evidence of improvements to the country's blue economy.

Thirdly, President Zuma's observation that Operation Phakisa is the result of a 'consultative process', including 'teams from government, labour, business, academia and other sectors to work together in experimental laboratories, to explore all possibilities and further unlock the potential of our country's vast coastline' (Zuma, 2014), seems hollow as very little evidence of the initiation and establishment of developmental coalitions in this respect exists. A developmental coalition can include an informal coalition such as 'teams' but then it should have some durability. It is, thus, unclear whether this 'consultative process' will be onceoff or on-going. However, of greater concern is the undemocratic nature of 


\section{AFRICAN \\ EAST-ASIAN \\ AFFAIRS

development in South Africa:

- Executive pre-eminence remains prevalent in development planning. Like Malaysia, where the PEMANDU is located in the Office of the Premier, the South African National Planning Commission (NPC) is located in the executive, i.e. The Presidency. Moreover, Operation Phakisa is also located in and managed by The Presidency, rather than the lead departments (Trade and Industry, and Fisheries).

- State transformation is not democratic and developmental transformation. Like the Chinese state, the South African state is also undergoing transformation in the image of the majority and ruling party, the African National Congress's (ANC), idea of a developmental state. However, in the case of South Africa, evidence of state capture emerges with corruption, so-called 'tenderpreneurship' (i.e. government officials who use their political influence to be awarded government tenders) (Nzimande, 2012), cadre deployment, and state-business relations really consisting of stateruling party business relations. Eskom, the state power utility, has awarded a contract for the construction of Medupi and Kusile, two coal-fired power stations, to, amongst other, Hitachi SA; a company partly owned by Chancellor House, the ANC's investment company. Moreover, the lack of developmental transformation means that certain patterns of development are perpetuated and do not lift South Africans out from the 'development trap'.

- Reform coalitions are currently absent. This is in contrast to the tenure of President Mandela that was, inter alia, characterised by the transformation of the state through the establishment of reform coalitions.

- Some developmental coalitions exist. Notable examples of this include the National Economic Development and Labour Council 
AFRICAN

EAST-ASIAN

AFFAIRS

(NEDLAC) and the NPC. However, these developmental coalitions are state-driven and supported; and are often reactive or simply dismissed. During his tenure in The Presidency, Trevor Manuel led the NPC that on one or more occasions rejected government's intention to proceed with the development of nuclear energy. The NPC's protests were simply dismissed.

Against the aforesaid, and in the context of this research, China and Malaysia offer some lessons for building democratic developmental states for economic transformation in South Africa:

- In both China and Malaysia, developmental leaders have contributed to development in the countries' nuclear energy sector and wider developmental sector respectively;

- Developmental leaders achieve relative success through the initiation and maintenance of development coalitions, which requires 'the building of formal or informal coalitions of interests, elites and organisations, both vertical and horizontal (Lyne de Ver 2009: 9);

- Inclusive developmental coalitions build and maintain democratic developmental states; resulting in state and societal transformation indicating 'fundamental shifts in the scope of state activities, bureaucratic capacities, purposes, instruments, and structures of authority' (Huber et al., 2015: 3-9, 13).

\section{Developing developmental leadership}

If developmental leadership is a determinant of developmental coalitions and development, the question arises: what is developmental leadership, and how is it developed and nurtured?

This article has defined developmental leadership earlier and repeats the definition here with annotations based on the aforesaid: 'the process [durability; thus, ongoing] of organising or mobilising [thus, action-driven and taken by one or more individuals offering material and non-material incentives and/or penalising] people 


\section{AFRICAN \\ EAST-ASIAN \\ AFFAIRS \\ THE CHINA MONITOR}

[thus, relational; human resources in and outside government] and resources [thus, material or non-material] in pursuit of particular ends or goals [objective or subjective; material or non-material], in given [thus, not in all] institutional [formal or informal] contexts of authority [the ability and power to act], legitimacy [the power designated to] and power [material or normative] (often of a hybrid kind). Achieving these ends, and overcoming the collective action problems [commonly shared concerns] which commonly obstruct such achievements, normally requires the building of formal or informal coalitions [mechanism] of interests [material or non-material], elites [in and outside government] and organisations [in and outside government], both vertical [in and outside government] and horizontal' [in and outside government] (Lyne de Ver, 2009: 9). ${ }^{1}$

The idea that leadership development can take place is widely recognised. In South Africa, for example, both the ANC and the opposition, the Democratic Alliance (DA) have leadership academies. Universities offer leadership courses and executive training if offered by institutions such as the UN and the World Bank. Moreover, leaders are elected or made, or dismissed via the ballot box or the bullet. As states and the global context change, the requirements for and from leaders change in scope, capacities, purpose, instrument, and structure of authority.

In order to assess the development of leaders in a developmental state, the emergence and resilience of leaders in China, Malaysia and South Africa is explored. In China, like in South Africa, political leaders emerge and are recruited from the ruling parties, i.e. the CCP and the ANC respectively. In Malaysia, ethnic ties often enable recruitment. Therefore, it seems that political associations prevail over merit; often resulting in leaders wanting to maintain the status quo as it is to his/her advantage. Therefore, leadership innovation and accountability, and thus, development, is stymied; and hence, Leftwich's (2009: 10-11) emphasis on 'fundamental political settlements' between opposing elites and domains (public or private) to 'establish, maintain and implement the locally appropriate, legitimate and feasible institutional arrangements which facilitate economic growth and (inclusive) social development'.

The development of developmental leadership can also benefit from greater 
AFRICAN

EAST-ASIAN

AFFAIRS

accountability in society. Undemocratic developmental states such as China with high levels of corruption do not foster developmental leadership. In this instance, the opening up of the Malaysian society has greatly enhanced the prevalence and quality of developmental leadership. In Southern Africa, for example, Botswana's success as a developmental state is based on its developmental leadership's ability to establish reform and later developmental coalitions with, for example, diamond giant De Beers and the establishment of Debswana, the state and De Beers-owned diamond company. A similarly example is the developmental leadership of the Bafokeng King in South Africa. Under the leadership of the Bafokeng King, the Royal Bafokeng Trust has been established to distribute the benefits of the tribe's platinum mines among members of the Bafokeng tribe.

Developmental leadership can also be developed through regional co-operation in order to 'overcome major collective action problems and/or major political, economic and social problems' (Leftwich, 2009: 10-11). In Southern Africa, for example, migration and environmental concerns are just two of the many developmental challenges facing more than one state in the region.

\section{Conclusion}

The article set out to analyse the concept developmental leadership in the context of declared and/or designated developmental states such as China, Malaysia and South Africa. It applied two case studies (nuclear power and oceans governance) to determine the applicability, impact and lessons from the Chinese and Malaysian experience for South Africa as a developmental state. South Africa regards both China and Malaysia as developmental models.

The contribution concludes that China and Malaysia are both different but also similar to South Africa. China's developmental state model in respect of its nuclear power is undemocratic, elitist, state-controlled and often secretive; similar to perceptions of the South African situation. In the case of Malaysia, the study concludes that the BFR as implemented in South Africa is too premature to reach conclusions; except to say that Malaysia's relative developmental progress is due to development coalitions and developmental leadership as defined earlier; aspects 


\section{AFRICAN \\ EAST-ASIAN \\ AFFAIRS

from which South Africa has already benefitted as Operation Phakisa has already been expanded to focus on the South African health sector. This, notwithstanding, the author is cognizant of the peculiarities of specific developmental context such as ethnically diverse or unequal societies.

The article has attempted to contribute to the concept of developmental leadership by focusing on some of the differences between democratic (Malaysia) and undemocratic (China) developmental leadership. It has argued that development is possible in both instances but that the benefit is likely to accrue to the state in states led by undemocratic development leaders who accumulate and distribute developmental benefits for political rather than developmental purposes. Against the aforesaid, the article calls a reconsideration of the concept developmental leadership to take cognizance of certain leadership realities (such as the increased recognition and role of traditional leaders such as the Bafokeng King mentioned earlier) in Africa. It also calls for the democratisation of developmental states in order for the emergence of developmental leaders based on merit.

\section{Endnotes}

1. Author's emphasis.

\section{Bibliography}

Alden, C, and Y. Wu. 2014. South Africa and China: The Making of a Partnership. Occasional Paper 199. Johannesburg: South African Institute of International Affairs.

AU (African Union). 2012. 2050 Africa's Integrated Maritime Strategy. [Online]. Available: http://www.au.int/maritime [Accessed: 17 November 2014].

AU (African Union). 2013. The AU 2050 Africa's Integrated Maritime Strategy Making Strides on the International Stage. [Online]. Available: http:// pages.au.int/sites/default/files/7_pic.jpg [Accessed: 17 November 2014]. 
AFRICAN

EAST-ASIAN

AFFAIRS

Baldwin, M.A. and Rose. P. 2009. Conceptual Analysis as a Dissertation Methodology. Nurse Education Today, 29: 780-783.

Balozi, M.A. Othman, S., and Issa, M.F.M. 2014. Constructing Theory with Big Fast Result Now (BFRN): Contribution of Tanzania to the theory of knowledge sharing behaviour. International Journal for Innovation Education and Research, 2(8):7-21.

Bolesta, A. 2015. China and post-socialist development. Bristol: Policy Press.

Cheng, J.Y.S. 2013. A Chinese view of Chinese energy security, in Zhao, S. (eds.). China's search for energy security. Domestic sources and international implications. New York: Routledge.

Cherp, A., and J Jewell. 2011. Measuring Energy Security, in B K Sovacool (eds), The Routledge Handbook of Energy Security. New York: Routledge.

Chow, G. 2015. China's economic transformation. Oxford: John Wiley \& Sons, Ltd.

Defence Review Committee. 2012. South African Defence Review. [Online]. Available: http://sadefencereview2012.org [Accessed: 17 November 2014].

Desta, A. 2012. The viability of the Malaysian developmental state for Africa in an era of economic globalization. International Journal of Business and Behavioral Sciences, 2(12):26-31.

Hameiri, S. and Jones. L. 2015. Rising powers and state transformation: The case of China. Paper presented at the International Studies Association Global South Caucus Conference, Singapore [Online]. Available: http://www.web.isanet.org, [Accessed: 19 June 2015].

Heywood, A. 1999. Political theory. An introduction. New York: Palgrave Macmillan.

Huber, E. et al. 2015. Introduction. Transformations of the state, in S Leibfried et al. (eds), The Oxford Handbook on the Transformations of the State. Oxford: Oxford University Press. 


\section{AFRICAN \\ EAST-ASIAN \\ AFFAIRS

Idris Jala, D S. 2014. New growth strategies: Perspectives from Malaysia's transformation program, World Bank Group Conference. [Online]. Available: http://www.worldbank.org [2015, June 19].

Jones Luong, P. 2015. Resources as constraints? Natural resource wealth and the possibility of developmental states in the former Soviet Union, in S Leibfried et al. (eds), The Oxford Handbook on the Transformations of the State. Oxford: Oxford University Press.

Leftwich, A. 2009. Bringing agency back in: Politics and human agency in building institutions and states. Developmental Leadership Programme Research Paper 06. [Online]. Available: http://publications.dlprog.org [Accessed: 19 June 2015].

Lyne de Ver, H. 2009. Conceptions of leadership. Developmental Leadership Programme Background Paper 04. [Online]. Available: http:// publications.dlprog.org [Accessed: 18 June 2015].

Malaysia (Government of). 2014a. Government Transformation Programme. [Online]. Available: http://www.pemandu.gov.my/gtp/Big_Fast_Result-@Big_Fast_Results.aspx [Accessed: 3 November 2014].

Malaysia (Government of). 2014b. What is transformation? [Online]. Available: http://pemandu.gov.my [Accessed: 19 June 2015].

Meidan, M., Andrews-Speed, P., and Ma, X. 2013. Shaping China's energy policy: actors and processes in Zhao, S. (eds.). China's search for energy security. Domestic sources and international implications. New York: Routledge.

Michel, J. A. 2015. Our blue horizons: Opening new development frontiers with the blue economy. Horizons, 2. [Online]. Available: http://www.cirsd.org/uploads/ magazines/pdf/James\%20Alix\%20Michel.pdf_1422004557_english.pdf [Accessed: 22 February 2016].

Nkoane-Mashabane, M. 2014. Minister of International Relations and Cooperation Budget Speech. [Online]. Available: http://www.pmg.org.za/briefing/20140722 
AFRICAN

EAST-ASIAN

AFFAIRS

-minister-international-relations-and-cooperation-budget-speech [Accessed: 6 October 2014].

Nzimande, B. 2012. Taking responsibility for the revolution: Advancing and deepening working class power in all key sites and fronts of struggle. Political Report to the 13th Congress of the South African Communist Party [Online]. Available: http://www.politicsweb.co.za/documents/blade-nzimandes-politicalreport-to-sacps-13th-con [Accessed: 25 April 2016].

Peiffer, C. 2012. 'Reform' coalitions. Patters and hypotheses from a survey of literature. Developmental Leadership Programme Concept Paper 03. [Online]. Available: http://publications.dlprog.org [Accessed: 18 June 2015].

PEMANDU (Performance Management and Delivery Unit of the Government of Malaysia). 2015. Government Transformation Programme (GTP) and the Economic Transformation Programme (ETP). [Online]. Available: http:// www.pemandu.gov.my [Accessed: 19 June 2015].

South African Government News Agency. 2014. Operation Phakisa to move SA forward. [Online]. Available: http://www.sanews.gov.za/south-africa/operation -phakisa-move-sa-forward [Accessed: 3 November 2014].

Tanzania Invest. 2013. Tanzania adopts Malaysian developmental model. [Online]. Available: http://www.tanzaniainvest.com [Accessed: 18 June 2015].

The Star. Tutu, De Klerk threaten boycott after Dalai Lama barred, 23 March 2009.

The Presidency. 2014. Operation Phakisa. [Online]. Available: http:// www.operationphakisa.gov.za/Pages/Home.aspx [Accessed: 3 November 2014].

UN (United Nations). 2014. Blue Economy Summit. Abu Dhabi, United Arab Emirates. [Online]. Available: http://www.sids2014.org/index.php? page $=$ viewandtype $=13$ andnr $=59$ andmenu $=1515 \quad$ [Accessed: 13 October 2014]. 


\section{AFRICAN \\ EAST-ASIAN \\ AFFAIRS

UNCTAD (United Nations Conference of Trade and Development). 2014. The Oceans Economy: Opportunities and Challenges for Small Island Developing States. UNCTAD/DITC/TED/2014/5. New York: UNCTAD.

WNA (World Nuclear Association). 2015a. Nuclear power in China. [Online]. Available: http://www.world-nuclear.org [Accessed: 19 June 2015].

WNA (World Nuclear Association). 2015b. Government structure and ownership. Nuclear power in China. Appendix 1. [Online]. Available: http://www.worldnuclear.org [Accessed: 19 June 2015].

World Nuclear News. CNNC signs framework agreement with Sichuan province. [Online]. Available: http://www.world-nuclear-news.org [Accessed: 19 June 2015].

Wu, G. 2015. Paradoxes of China's prosperity. Political dilemmas and global implications. Singapore: World Scientific Publishing Company.

Zhao, S. (eds). 2013. China's search for energy security. Domestic sources and international implications. New York: Routledge.

Zuma, J. 2014. Address by President Zuma at the Operation Phakisa: Unlocking the Economic Potential of the Ocean Economy Open Day. International Convention Centre (ICC), Durban. [Online]. Available: http://www.gov.za/ speeches/view.php?sid=49293 [Accessed: 16 October 2014]. 
